\title{
Simulating Discount-Pricing Strategies for the GSM-Mobile Market
}

\author{
Achieving a successful market entry on a network effect market is a great challenge. The \\ pre-existing customer base of competitors will usually force a new supplier to concede in \\ order to entice other companies' customers away and to compensate for network effects. The \\ cell phone market shows a special form of network effects that arises from different pricing \\ for on-net and off-net calls. Simulation models can help to estimate consequences of pricing \\ strategies for different components of a cell phone contract even prior to market entry.
}

DOI 10.1007/s12599-009-0057-0

\section{The Authors}

Dipl.-Kfm. Sven Schade Dipl.-Wirtsch.-Inf. Thorsten Frey Dipl.-Wirtsch.-Ing. Nezar Mahmoud Technical University of Darmstadt Department of Information Systems Hochschulstr. 1

64289 Darmstadt

Germany

\{schade|frey\}@is.tu-darmstadt.de nezar.mahmoud@googlemail.com

Received: 2008-03-28

Accepted: 2008-09-25

Accepted after one revision

by Prof. Dr. Buhl.

This article is also available in German in print and via http://www. wirtschaftsinformatik.de: Schade S, Frey T, Mahmoud N (2009) Simulation von Diskontpreis-Strategien im GSM-Mobilfunkmarkt. WIRTSCHAFTSINFORMATIK. doi: 10.1007/11576-0090178-6.

\section{Introduction}

The cell phone market is explored in different research areas, for example in studies upon regulation (Carter and Wright 1999; Blonski 2002; Haucap 2004; Kruse 2003), the diffusion of technologies (Church and Gandal 2004; Koski and Kretschmer 2005) or game theoretic analysis of, for instance, UMTS licensing.

Furthermore, the cell phone market is an interesting field for studies of network effects which are also focused in this article. We look at network effects resulting from cost advantages that arise if a cell phone user communicates with other customers of the same cell phone provider. Our analysis of the cell phone market begins with a modeling of network effects for individuals by means of an agent based simulation.

The commonly used term for analyzing economic issues with agent-based models is "Agent-based Computational Economics" (ACE). According to Tesfatsion (2003, p. 2) ACE incorporates dynamically interacting agents for computerized analyses of economic issues. Usually, ACE methods implement a bottom-up approach as their modeling corresponds to a system's micro-economic level while they provide results on a rather macro-economic level. This approach seems applicable to the cell phone market since market shares result from many customers' buying decisions. The relationships between the cell phone market's customers represent some kind of peculiarity that can be modeled as a network. We thereby manage to merge aspects of social networks with agentbased simulation.

A successful entry into a saturated market like the cell phone market is difficult to accomplish, last but not least due to the tremendous amount of designable parameters of a cell phone contract. In this respect, the possibility to estimate success in advance would be very helpful. Therefore this article aims to map the individual network effects in the cell phone market into an ACE simulation in order to estimate the chance of success of a newcomer's market entry, pursuing a discount pricing strategy.
In the following we present an overview of the cell phone market and a short classification. A brief literature review shows the state of research about the cell phone market. Section 3 describes the simulation model we have developed and outlines a basic simulation run. Afterwards section 4 presents and evaluates the simulation results of a market entry scenario as well as the model's limitations. The article concludes with an overview and an outlook to possible extensions.

\section{Market overview and current state of research}

In the following we describe some facts and figures about the German cell phone market as well as its most relevant actors. We then depict the current state of research and relate it to this article. At first, we start with a brief definition of terms in order to clarify which mobile communication offers are the main focuses of this article.

The term "mobile communication" applies to a multitude of wireless technologies, i. e. GSM and UMTS, amateur and police radio, WiMAX, WLAN, Bluetooth or wireless phones (BMWi 2008). The German Federal Network Agency distinguishes between "cell phone services" and "other mobile communication services" (Bundesnetzagentur 2007a). In this article we refer to cell phone services in GSM networks by using the term "cell phone market”. Regarding Germany this includes the D- and E-cell phone network. 


\subsection{The German cell phone market}

One can distinguish between several providers on the cell phone market - in particular between providers of cell phone contracts, vendors who sell contracts from different providers and suppliers of complementary goods (e. g. cell phones or infrastructure). In our analysis we exclude vendors and suppliers of complementary goods but focus on providers of cell phone contracts. These can be further distinguished in mobile communication providers with and without an own network. The latter are intermediates between cell phone customers and network carriers, as they buy spare capacities from carriers and resell these capacities in the form of own contracts.

The cell phone market in Germany is subject to the regulation by the Federal Network Agency, especially with regard to termination rates. A provider has to pay a termination fee if one of his customers calls a person who uses a different provider's network. Therefore providers have to account for these external costs as lower pricing bounds. The Federal Network Agency fixes limits for these termination fees. However, we do not focus on regulation aspects in this article.

In 2006 the sales volume of the German telecommunication market accounted for 69 billion Euros, to which the cell phone market contributed $42 \%$ (Dialog 2006, p. 6). Four main network carriers (TMobile, Vodafone, E-Plus and O2) held the bulk market share of $75 \%$ in Germany. The remaining $25 \%$ are held by the six biggest service providers Debitel, Mobilcom, Talkline, Drillisch, The Phone House and Tangens (Bundesnetzagentur 2007c). The total time volume of cell phone connections has increased continuously since 1998 from 22 million to 127 million minutes in 2006 (Dialog 2006, p. 24). Likewise the penetration rate increased continuously since 1990 and exceeded $100 \%$ in 2006. Statistically this implies one cell phone contract for each person in Germany. Although countries like Italy show that penetration rates of $118 \%$ are possible, the diffusion rate in Germany underlies saturation tendencies leading to a change in competition (Ebert et al. 2006, p. 32). The subsequent cutthroat competition led to a decrease of the cell phone market's growth rate (regarding customer acquisition) from $10 \%$ to $5 \%$ between 2004 and 2006. A further decrease to $3 \%$ has been forecasted (Bitkom 2006, p. 9). Due to the extensive saturation of the cell phone market the impact of network effects can by analyzed in a rather stable social network.

\subsection{State of research with regard to the cell phone market}

In this section we examine existing research articles about aspects of the cell phone market like provider and tariff selection, switching costs and especially network effects. Important results of these contributions are highlighted and applied to this article.

\section{Network effects}

According to Katz and Shapiro (1986) network effects exist if the benefit a consumer receives from a good is altered by the fact that other people also consume this good. Katz and Shapiro distinguish between two different kinds of network effects. Direct network effects exist, if a direct physical effect between the consumers of a good provides the basis for the additional benefit - like the exchange of information in communication networks. Fax machines or video cell phones provide further examples. In case of indirect network effects the benefit generated by some good increases with the availability of complementary goods and services, e. g. consulting services for software introductions or a greater variety of terminal equipment for the cell phone market.

There are a great number of contributions on network effects. For a more comprehensive description of the research in the network effect theory the interested reader is referred to David and Greenstein (1990), Weitzel et al. (2000) and Koski and Kretschmer (2004).

However, there is also criticism regarding the network effect theory. In the following we briefly pick up this critique in order to show that the cell phone market provides an appropriate example to clarify unexplored aspects. Amongst others Weitzel et al. (2000) observe that network effects have been greatly simplified in existing models. For example, a linear relation between the network size (i. e. the number of participants in the market) and the present network effects is often assumed. Usually there is no differentiation between network effect benefits caused by new participants and by partic- ipants who entered the market at an earlier point of time. Furthermore, homogeneous network effects are often presumed, which means that every user provides the same benefit to all other users. Therefore Weitzel et al. propose that models should account for social and economic interactions between market participants, meaning that incomplete information, uncertainty and different levels of rationality should be incorporated. Weitzel and König (2003) call for agent-based computational economic approaches to combine these aspects. Following that, for example Beck et al. (2003) use a multi agent based simulation for analyzing the diffusion of WAP and i-mode on the basis of network effects.

The existence of network effects on the cell phone market could be proven. Grajek (2003) empirically analyses the demand for cell phone services on the basis of quarterly data from 1996 to 2001 and comes to the conclusion that the Polish cell phone market would be smaller by a factor of 15 in absence of network effects. Doganoglu and Grzybowski (2006) present similar results for the German cell phone market. Between 1998 and 2003 the number of participants increased by $700 \%$, while prices only decreased moderately by $41 \%$. According to the authors' estimation, the German cell phone market would be smaller by a minimum factor of two without the existing network effects. Respectively a much greater reduction in prices would have been necessary to achieve the same penetration rate.

In this article we incorporate one peculiarity in regard to network effects in the cell phone market. While network effects are usually examined in combination with a technology's diffusion on an unsaturated market, our analysis focuses on a rather saturated market. The entry of new customers to the cell phone market occurs by concluding a new contract with a cell phone provider. However, this article does not focus on new contracts (i. e. contracts with customers that did not conclude a contract before). We rather examine how existing customers are allocated to the different cell phone networks and analyze network effects that arise for a customer from the selection of a certain provider. These network effects are caused by the fact that cell phone providers differentiate between phone calls within their own cell phone network and calls from their network to the one from a different provider. 


\section{Business oder Technologie?}

\section{Wieso oder?}

\section{Oder kennen Sie ein Business,}

\section{das ohne Technologie auskommt?}

McKinsey sucht Berater(innen) für das Business Technology Office.

Der effektive Einsatz von Technologie löst unternehmerische Probleme und steigert somit den substanziellen Wert eines Unternehmens nachhaltig. Genau das ist das Ziel unserer Beratung. Wir helfen unseren Klienten, Investitionen in Technologie erfolgreich zu managen und mit den strategischen Prioritäten des Geschäfts in Einklang zu bringen. Wenn Sie diese vielfältige Herausforderung annehmen, werden Sie auf über 500 Kollegen an rund 50 Standorten in mehr als 25 Ländern treffen. Und werden damit Teil des globalen Business Technology Office - eines der größten und am schnellsten wachsenden Büros von McKinsey \& Company. Alle weiteren Informationen finden Sie auf unserem Karriereportal. 


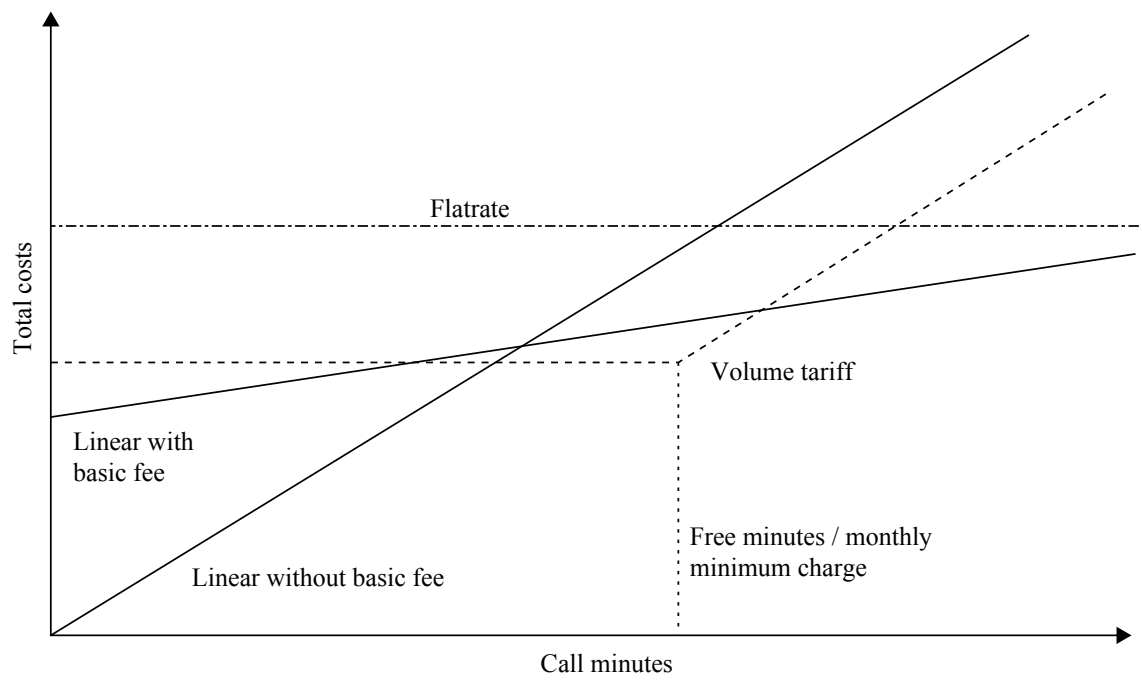

Fig. 1 Possible combinations of fixed and variable shares of costs in cell phone contracts

The customer benefits from these network effects in the form of lower fees for calls within his provider's cell phone network. The "off-net fees" for calls to different cell phone networks tend to be significantly higher than "on-net fees" for calls inside the same network, due to termination rates. In that case it is thereby possible to account for network effects not only in form of abstract units of benefit, but to incorporate them into the model as a monetarily assessed parameter on the basis of connection time and prices. Given equal contract conditions and equal services, differences between on-net and offnet fees offer an incentive for customers to select a provider with the greatest customer market share. Furthermore, telephone costs do not longer only depend on a customer's connection volume, but also on the distribution of his conversation partners on different cell phone networks. A customer spending 100 call minutes per month solely in his provider's cell phone network will usually face much lower costs than a customer who is spending the same amount of connection time with other networks' participants.

\section{Tariff choice}

The contributions by Iyengar (2004) and Iyengar et al. (2007) analyze the decision behavior of cell phone customers based on a structural model and Bayesian statistics. The authors use monthly invoice data of an American cell phone provider and simulate how customers decide between fictive volume contracts based on cost, quality and amount of usage. However, differences between on- and off-net fees and thus relations between cell phone customers remain unconsidered.

\section{Provider selection}

Bolle and Heimel (2005) examine to which degree customers correctly estimate the relation between market share and onnet/off-net fees when selecting a cell phone provider. Their empirical study shows that customers, lured by low prices, jump to smaller providers although the assumed advantage of lower prices is compensated by a higher rate of off-net calls that might even result in higher amounts invoiced. Although the interviewees were aware of the fact that the provider's market share has an impact on overall costs, they underestimated this effect. Thus $65 \%$ of the respondents were tricked by a dominant price vector given a fixed distribution of calls. Although the survey was not representative, the results reveal some interesting phenomena. The respondents ranked a cell phone provider's market share as the least important criterion, whereas the cell phone network of their friends and family played a major role for provider selection. This is another reason for a close linkage of social networks and network effect theory, since individual relationships between the actors can be incorporated by this means (Weitzel et al. 2000). According to this, in our article we model social relationships between cell phone users by representing them as edges of a network and examining their influence on customer decisions.

\section{Switching costs}

Kim et al. (2004) analyze the impact of customer satisfaction and switching barriers on customer loyalty in the Korean cell phone market based on empirical data. They note that quality aspects as well as switching costs have a great impact on customer loyalty and therefore on the propensity to switch. Shin (2005; Barabási and Albert 1999) also clarifies the importance of switching costs and barriers. By means of an empirical survey he seeks for reasons why the introduction of phone number porting in the USA did not lead to the expected amount of customers changing their provider. He shows that high switching costs prevented that. Due to their importance, switching costs will be incorporated in this article. However, we include them by means of an aggregated parameter instead of single factors.

\section{An ACE approach for simulating market shares in the cell phone market}

In this section we present an agent based approach which incorporates the relations and effects on the cell phone market relevant for our analysis. Since cell phone contracts represent relations between customers and providers, we begin with explicating the characteristics of a cell phone contract. Following that, the simulation model and its flow as well as the roles and the behavior of the individual actors are explained.

\subsection{Overview of contract characteristics}

A customer's entry to the cell phone network results from his selection of a cell phone contract, referred to as "tariff" in the following. A study about tariffs of German cell phone providers, which we conducted at the beginning of 2007 , revealed that these tariffs can be characterized by the following attributes.

\section{Prepaid / post-paid}

The customer can either pay a certain amount in advance and use this deposit (Prepaid) or pay a monthly bill afterwards (post-paid). The usual post-paid contract duration is 24 months; prepaid contracts usually do not include a minimum duration. 


\section{Fixed / variable shares of costs}

The possible combinations of fixed and variable shares of costs are depicted in Fig. 1.

Linear tariffs without a basic fee are common in the prepaid sector. Other kinds of tariffs like flat rates, volume tariffs and linear tariffs with a basic fee are rather common in the post-paid sector.

\section{Differentiation by time}

The charge per minute can be distinguished further by weekday (workday, weekend) and by time of day (prime time and secondary time). Due to their complexity such tariffs have become rare in the sector of private customers.

\section{Differentiation by target network}

A differentiation of charges per minute subject to the target network (on-net or off-net) is common, not least due to termination fees. Off-net calls can furthermore be priced differently according to the respective cell phone network or landline network.

\section{Billing increment}

Contracts can be distinguished regarding the billing increment for the first and the following minutes (1, 5, 10 or 60 seconds). The customer has to pay for every commenced "time slot".

\section{Regional belonging}

The spatial position of a caller is another criterion for distinguishing charges per minute. Certain tariffs offer lower charges if the caller is located inside a certain area during the call (e. g. the so-called "home zone" by $\mathrm{O} 2$ ). This applies to calls from a certain area ranging from a few hundred meters up to several kilometers around a certain, frequently visited address.

Further differentiators of tariffs are the acquisition fee (for new contract conclusions) as well as conditions for mailbox queries, SMS, MMS or subsidized cell phones.

These different characteristics and possible combinations show that a great variety of tariffs is imaginable - and is indeed offered on the market. In our survey conducted at the beginning of 2007 we found more than 40 different kinds of tariffs, including linear tariffs offered by dis-

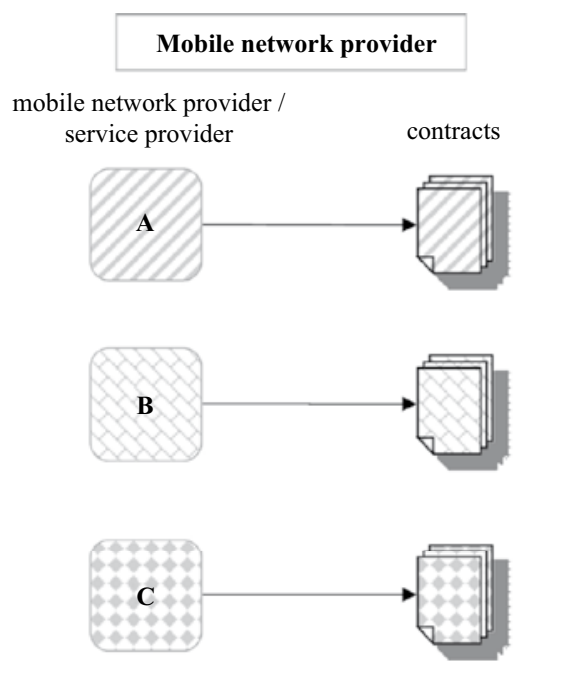

Fig. 2 Actors in the simulation model

counters, special tariffs with lower prices for Turkish landline and cell phone calls, or for landline calls to regions like SchleswigHolstein, up to flat rates with free of charge calls in all national networks. The onnet fees varied between 5 and 49 (Euro-) Cent per minute, the off-net fees varied between 19 and 62 Cent.

\subsection{The simulation model}

The contracts described previously were analyzed in a simulation model, which incorporates the different aspects of a contract. The basic design of this model is depicted in Fig. 2.

At first we define cell phone providers and different contracts for each provider. Afterwards agents representing the cell phone customers are created (nodes in the right part of Fig. 2). On the basis of market shares, these customers are distributed over the providers. One of the contracts offered by the respective provider is then assigned to every customer. Afterwards, the edges between the nodes are created and are weighted with call minutes. After this initialization, customers whose contract duration time is nearly expired decide in every period if they want to conclude a new contract of their current or a new provider. They select the contract that minimizes their costs given their calling behavior and their conversation partners' providers. The simulation can be stopped when equilibrium or a certain number of periods is reached.

In the following we introduce the actors and the corresponding parameters in detail.

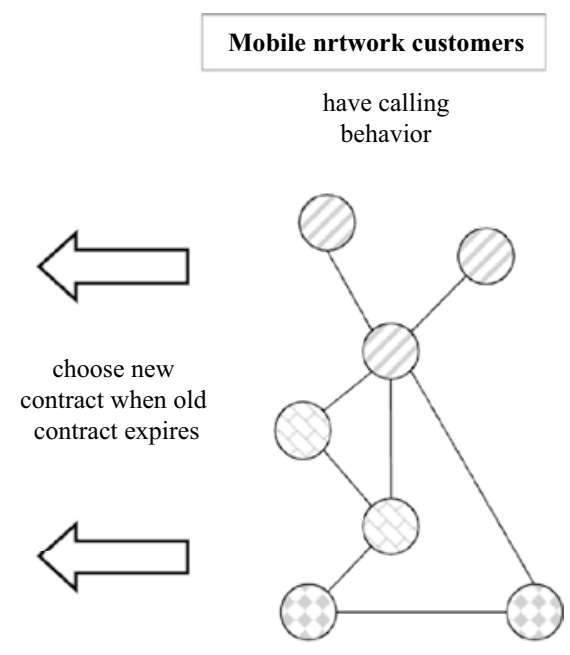

\section{Providers and contracts}

Before the simulation run starts, the number of customers and the kind of contracts are specified for each provider. In our model contracts are static which means that their parameters do not change over time.

In our model contracts are characterized by the following parameters:

- Type of contract (home zone, flat rate, volume tariff, linear tariff)

- Contract duration (ranges between 0 and 24 months)

- Acquisition fee

- Basic fee for a contract variant with and without a new cell phone

- Minimum call volume per month

- Free volume of calls per month

- Off-net fee

- On-net fee

- Fee for landline calls

- Mailbox fee

Furthermore, home zone tariffs also include the four parameters on-net fee, off-net fee, fee for landline calls and mailbox fee for calls initiated from within the home zone.

By trend, prepaid customers show a higher contract-switching rate than postpaid customers. Our model incorporates this fact by setting the contract duration to zero for prepaid contracts. Thus, customers with this kind of contract can change their provider in every period of time. However, prepaid customers as well as post-paid customers face switching costs that counteract the switching dynamic. 


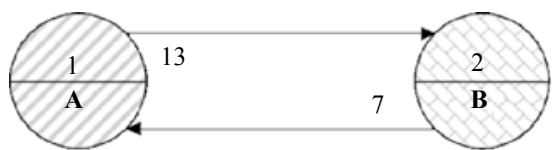

Fig. 3 Communication relationships of cell phone customers

\section{Customers}

Cell phone customers in the simulation model act as autonomous agents. They are represented by nodes and relate to other customers by their phone calls. These calls are represented by edges between the nodes (Fig. 3). The node degree is given by the number of people a customer calls each month. This node degree is important for creating certain kinds of network topologies. The weights of the edges represent the number of minutes a customer spends for calls to another customer per month (customer 1 talks to customer 2 for 13 minutes). Customers are related to a certain provider based on their contract (customer 1 is related to provider A). It is assumed that each customer knows the mobile network providers of all direct conversational partners.

Furthermore, there are other properties describing a customer's monthly usage pattern:

- Monthly mobile-to-landline calling minutes

- Monthly mailbox calling minutes

- Appreciation for a cell phone

- Switching costs

- Home zone share (share of calling minutes from within the customer's home zone in relation to all calling minutes)

- Monthly costs for landline-to-landline calls

- Willingness to substitute (the share of landline-to-landline calls a customer is willing to substitute by mobile-tolandline calls if the latter are free of charge)

Since the simulation focuses on the analysis of network effects in the context of voice services, the model does not account for costs for data services like SMS or MMS.

\section{Decision behavior}

In the simulation model, at every point of time a contract is assigned to each customer. This contract has a remaining duration. If this remaining time is three months or less, an agent starts to show interest in a new contract and calculates the monthly costs for every available contract according to the following formula:

basic fee $+\frac{\text { acquisition fee }}{\text { contract duration }}+$ call fees +
switching costs $+\frac{\text { remaining costs for old contract }}{\text { contract duration }}$

At first, the monthly basic fee of the new contract is assigned to the arising costs. If there is no basic fee (e.g. for prepaid contracts) this parameter is set to zero. In case of a provider change the acquisition fee is divided by the expected duration and added to the contract costs.

The call fees consist of the costs arising from the customer's calls to other conversation partners in consideration of the new contract's conditions. For customers with a home zone or flat rate contract these costs are reduced by the savings via landline call substitution. Landline call substitution is modeled by the given share of landline-to-landline call costs that can be omitted if one of the contracts mentioned above is chosen.

In reality the decision behavior of a customer is also determined by aspects like customer loyalty, general unwillingness to switch from the current provider or accommodativeness. These aspects might prevent a customer from switching to a new provider. In the model they are aggregated to a monetary parameter (switching costs) for every agent. Every agent accounts for theses costs when he assesses a contract of a new provider. In our model switching costs can be interpreted as a monetary barrier for switching to a new provider. These costs are equal to the amount by which a new contract has to be cheaper than the old one so the customer is willing to bear the troubles of switching to a new provider.

Three months before expiration of the existing contract the customer is allowed to change his provider immediately. However, he has to pay the remaining basic fees of his old contract and thus incorporates these costs into his calculation. The model considers that by dividing the sum of prepayments by the expected duration of the new contract. This quotient is added to the monthly costs.

Post-paid contracts are usually available with or without a new cell phone. For contracts in combination with a cell phone the basic fee is higher due to subvention of the cell phone. An agent assumes that he has to pay for the phone via a share of the monthly basic fee. Every customer has a certain appreciation for a cell phone. This appreciation and the higher basic fee are taken into account when considering a new contract. If the appreciation is higher than the additional costs (difference of the basic fees for both contract versions) the customer prefers the contract with a cell phone. Analyzing the differences between different mobile phones is beyond the scope of this article. Therefore the customer's appreciation is modeled by a general parameter applying to all kinds of cell phones.

This calculation is performed for all contracts. A customer with an expired contract selects the cheapest contract according to this calculation. Customers only change their contract in advance of the expiration date if the costs of the new contract including the prepayments are lower than the costs caused by the old contract.

\section{Initialization of parameters}

At the beginning of every simulation run the number of customers is specified for each provider. Then, one of the provider's contracts is randomly assigned to every customer. The remaining duration time is set to a random, equally distributed value between 0 and 24 month (for prepaid contracts the remaining duration time is always zero). According to the initial parameters a node degree distribution is determined and calling minutes are assigned to the network's edges.

The random assignment of contracts to customers creates a rather high degree of disorder at the beginning of a simulation run. Some frequent callers possibly have been assigned to a prepaid contract and some infrequent callers might have been assigned to a flat rate contract which leads to a high willingness to switch. However, this does not influence the market result at the end of the simulation because during the simulation every customer has the chance to select the best contract. This decision does not depend on how adequate the old contract was. In theory, the initial remaining contract durations could affect the result of the simulation due to changed points in time for decision making. However, simulation runs with short initial remaining contract durations have shown that (after a sufficient amount of periods) the same market result emerges as in simulation runs with random initial remaining durations. 


\section{Simulation results}

To show how the simulation model introduced in this article can be used for analyzing economic questions regarding the cell phone market, several simulation runs have been conducted with different provider and contract constellations. The main focus addresses the simulation of a market entry scenario in order to analyze the impact of different contract aspects on the market share. To facilitate the comparability of these results, an initial simulation was performed based on the current market situation in Germany.

\subsection{Scenario without a new provider}

Although the simulation model includes many simplifications, usage data from real contracts and empirical studies (Destatis 2004; Stiftung Warentest 2006) were used in order to check whether the model reflects the current developments in the cell phone market by trend. Furthermore, this scenario can be used as a comparative scenario for other analyses. On the supply side the four German cell phone providers with an own network were incorporated on the basis of 30 real contracts (Tab. 1). Most of these contracts were prepaid, volume, flat rate and home zone contracts (except for E-Plus) which have been characterized in section 3.1. The group of service providers was excluded, because we present an isolated examination of the market entry of a new provider in the next section.

In all simulation runs the demand side was represented by modeling 100,000 cell phone customers. The actual number of cell phone customers in Germany is much higher. However, only a subset of customers could be represented due to limited computing resources. Simulation runs with different numbers of customers between 1,000 and 100,000 showed that in our model the size of the network has no influence on the market result as long as the distribution of the node degrees is held constant. The allocation of providers to the different customers is based on subscriber market shares in 2006 (T-Mobile: $36.6 \%$, Vodafone: $35.7 \%$, E-Plus: $14.8 \%$, O2: $12.9 \%$ ) (Bundesnetzagentur 2007b).

In general, the simulation model supports different, computer-generated topologies. For example, the simulation can be based on a scale free network (Barabási and Albert 1999), which has been employed before in similar approaches for analyz-

\begin{tabular}{|c|c|c|c|c|}
\hline Type of contract & T-Mobile & Vodafone & E-Plus & 02 \\
\hline prepaid & Xtra Classic & Call Ya & Free \& Easy & Loop \\
\hline volume & & & & Active 25 \\
\hline volume & Relax 50 & Minutenpaket 50 & Time \& More 50 & Active 50 \\
\hline volume & Relax 100 & Minutenpaket 100 & Time \& More 100 & Active 100 \\
\hline volume & Relax 200 & Minutenpaket 200 & Time \& More 200 & Active 250 \\
\hline volume & Relax 400 & Minutenpaket 500 & Time \& More 500 & Active 500 \\
\hline volume & Relax 1000 & & & \\
\hline flat rate & Max & SuperFlat & Base & Genion L \\
\hline home zone & $\begin{array}{l}\text { Basix, T-Mobile@ } \\
\text { home }\end{array}$ & CombiComfort & & $\begin{array}{l}\text { Genion S, } \\
\text { Genion MM }\end{array}$ \\
\hline
\end{tabular}

Tab. 2 Overview of usage profiles for cell phone customers

\begin{tabular}{|c|c|c|c|}
\hline Attribute & Infrequent callers & Average callers & Frequent callers \\
\hline Subscriber market share: & 0.6 & 0.25 & 0.15 \\
\hline $\begin{array}{l}\text { Average number of mobile } \\
\text { minutes per month:* }\end{array}$ & 53 & 170 & 250 \\
\hline $\begin{array}{l}\text { Average number of } \\
\text { communication partners:* }\end{array}$ & 3 & 9 & 20 \\
\hline $\begin{array}{l}\text { Mailbox queries' proportion } \\
\text { of mobile minutes:* }\end{array}$ & 0.05 & 0.05 & 0.05 \\
\hline $\begin{array}{l}\text { Landline call proportion } \\
\text { of mobile minutes:* }\end{array}$ & 0.3 & 0.3 & 0.3 \\
\hline $\begin{array}{l}\text { Average appreciation for subsidized } \\
\text { hardware (in } € / \text { month):* }\end{array}$ & 6 & 8 & 10 \\
\hline $\begin{array}{l}\text { Average costs for landline-to- } \\
\text { landline-calls (in } € / \text { month): }\end{array}$ & 8 & 10 & 12 \\
\hline $\begin{array}{l}\text { Willingness to substitute mobile } \\
\text { calls with landline calls: }\end{array}$ & 0.2 & 0.2 & 0.3 \\
\hline Switching costs (in $€ /$ month): & 5 & 6 & 7 \\
\hline $\begin{array}{l}\text { Home zone proportion } \\
\text { of mobile minutes: }\end{array}$ & 0.5 & 0.4 & 0.3 \\
\hline
\end{tabular}

ing communication networks (Hein et al. 2006).

However, the simulations described in the following were based on a topology build on three prototypical usage profiles for "infrequent callers", "average callers" and "frequent callers". Values used for parameter initialization are given in Tab. 2. The profiles are based on usage data provided by the German Federal Statistical Office and Stiftung Warentest (Destatis 2004; Stiftung Warentest 2006). Since the surveys provided by the two different sources were not congruent with regard to survey time and attributes, parameters had to be adjusted and parameter values had to be estimated due to the lack of empirical data.

The dialogue partners of an agent are distributed on the target networks with respect to the attributed cell phone provider (Provider affiliation: on-net/off- net share): T-Mobile: $50 \%$ / $50 \%$, Vodafone: $50 \%$ / $50 \%$, E-Plus: $25 \%$ / $75 \%$, O2: $20 \% / 80 \%$ by means of a Poisson distribution. That means, during the creation of the network e. g. an E-Plus customer with eight dialogue partners on average was assigned to two randomly chosen EPlus customers and to six randomly chosen customers of other networks.

All simulations were conducted over 36 periods. The development of the market shares is depicted in Tab. 4 (first row "Scenario without entry of a new provider"). The market share of $\mathrm{O} 2$ increases significantly under all given conditions. The market shares of T-Mobile and Vodafone decrease, the market share of E-Plus only changes marginally. Almost two thirds of $\mathrm{O} 2$ customers chose the volume contract "O2 active 250" at the end of the simulation and further $20 \%$ chose the home zone tariff "O2 Genion S". Vodafone cus- 


\begin{tabular}{|l|llllll}
\hline Acquisition fee & $\begin{array}{l}\text { Basic fee for a contract with- } \\
\text { out a cell phone }\end{array}$ & Minimum charge & On-net fee & Off-net fee & $\begin{array}{l}\text { Fee for landline } \\
\text { calls }\end{array}$ & $\begin{array}{l}\text { Fee for mailbox } \\
\text { calls }\end{array}$ \\
\hline $19.95 €$ & $0 €$ & $0 €$ & $0.05 €$ & $0.25 €$ & $0.25 €$ & $0 €$
\end{tabular}

tomers exclusively selected the linear tariff "Call Ya". Almost three fourths of E-Plus customers chose the volume tariff "Time \& More 50" and further $20 \%$ the volume tariff “Time \& More 200". Almost eighty percent of T-Mobile customers subscribed to the "Relax 50" volume tariff, while $16 \%$ selected the volume tariff "Relax 200". It turned out that flat rate tariffs were not selected during the simulation runs, due to high monthly costs associated with these contracts. Instead, volume tariffs predominantly lead to minimal costs as long as no cheap linear tariff was available in the provider portfolio.

\subsection{Market entry of a new provider}

The entry of a new provider in a market with network effects is frequently investigated in literature. For example, research on the software market has shown that penetration pricing is a promising strategy for the market entry of a new provider (Buxmann 2002).

Penetration pricing strategies belong to the class of dynamic pricing strategies. They are characterized by low prices at the beginning and increasing prices over time (Pepels 1998, p. 83). The basic idea of a penetration pricing strategy on a network effect market is to initially create network effects by a low entry price. Then, due to the increased network effect benefits resulting from an increased number of customers, the price can be raised successively. In the following, however, a pure low price strategy (discount price strategy) will be analyzed, i. e. a low entry price is set for the whole focused period of time (Pepels 1998, p. 81). The main reason for this decision is the consistent decline in prices on the cell phone market in recent years (Destatis 2008). Therefore, increasing prices over time seem to be unrealistic for the cell phone market. Moreover, the usual contract durations restrain the providers' possibilities to increase prices for existing customers at an arbitrary point of time. Thus, the penetration pricing strategy identified as a promising approach in many articles cannot be transferred to the cell phone market. Although the simulation model described here can be used for modeling dynamic strategies, we do not change prices during the considered periods because this makes it easier to understand how different aspects of a contract influence the market share of a provider.

In the following we analyze the market entry of a new provider without an installed base. In order to draw conclusions about the influence of different components of a contract, the new provider is only equipped with a single contract. For the simulation runs presented in this article we chose a prepaid contact, since this kind of contract is rather common for service providers. Furthermore, this decision seems appropriate since prepaid contracts have a short duration time and thus are suitable for the market entry of a new provider. Within the scope of our analysis a contract was designed, containing the cheapest conditions of all existing prepaid contracts (see Tab. 3). Interestingly this new contract was equal to Vodafone's "Call Ya"-tariff, which means that this tariff was the cheapest prepaid tariff regarding all parameters under consideration.

Based on this contract the different fees were altered ceteris paribus. For every new variant of the contract the simulation was done for 36 rounds (months) to calculate the market share of all providers. The results are presented in Tab. 4.

In the initial situation (i. e. imitating the cheapest contract) the fictitious provider could not overcome the start-up problem. The lack of network effects for potential customers of the new provider and switching costs on the consumer-side prevented customers from choosing the new provider.

With regard to a discount pricing strategy on the cell phone market, lowering the off-net fee seems to be a promising approach. Pursuing a discount pricing strategy by means of low on-net fees on the other hand does not seem to be appropriate, because the customers only benefit from a low on-net fee if there is an installed base. However, it has to be mentioned that the possibility of new customers forming a cluster and deciding in favor of the new contract due to a lower on-net fee is neglected.
Cutting the on-net fee as well as setting the acquisition fee to 0 Cent caused the same result as in the initial situation: the provider did not succeed in acquiring new customers.

The simulation with a varied off-net fee showed that cutting the off-net fee to 15 Cent/minute lead to the acquisition of several customers by the new provider. But even then the market share of the fictive provider was too low (1.3\%) for a successful establishment. A further cut to 12.5 Cent/minute resulted in a long-run market share of $23.1 \%$. A fee of $10 \mathrm{Cent} / \mathrm{min}$ ute enabled the new provider to establish itself as the market leader.

The simulation of a strategy based on cutting the fee for landline calls showed that these fees had to be lowered down to $5 \mathrm{Cent} / \mathrm{minute}$ in order to realize a market share of $1.4 \%$. However, this neglects the fact that the share of landline calls in the total call minutes might increase due to cheaper landline call fees.

The granting of 15 free minutes to the customer lead to a market share of $2.9 \%$, while granting 30 free minutes lead to market leadership with a share of $41.4 \%$. However, such a strategy cannot be pursued for a long time for contracts without a basic fee, since termination rates have to be paid for calls in other networks.

Apart from that, it turns out that a drastic reduction in prices compared to the competitors is mandatory to overcome the start-up problem at the cell phone market. This applies at least to prepaid contracts and remains true as long as other providers do not react by modifying their contracts.

\subsection{Most important results}

The simulation results show that a new provider has to accept a considerable cut in prices to successfully establish on the market. A low off-net fee for prepaid contracts has a higher chance of success than a low fee for landline calls. An exclusive cut in on-net fees for capturing market shares in the beginning is not practical as well as an uncoupled abdication of the acquisition fee. The simulation results show that in principle a successful market entry can 


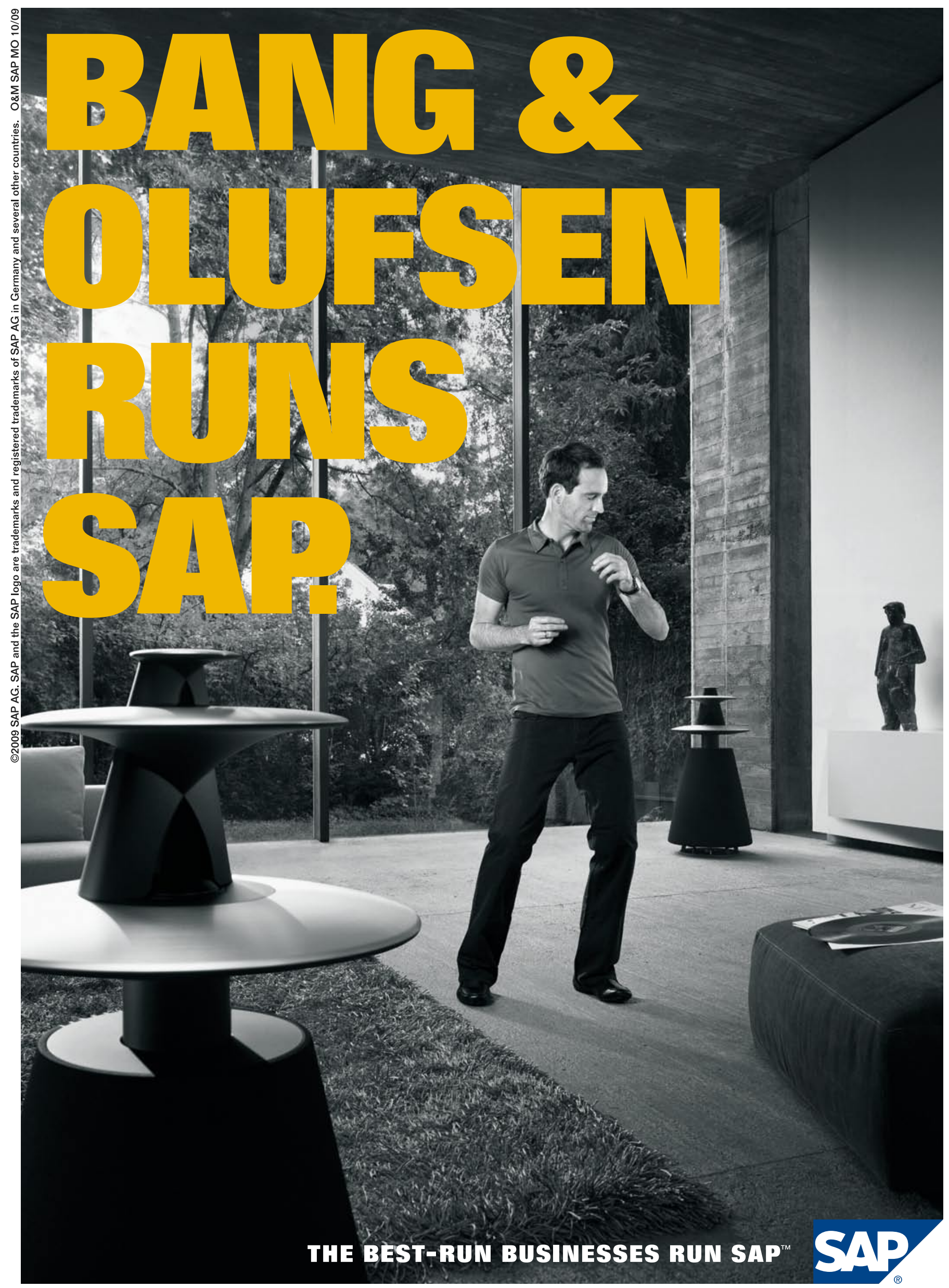




\begin{tabular}{|c|c|c|c|c|c|}
\hline \multirow[b]{2}{*}{ Fee / minutes } & \multicolumn{4}{|c|}{ Market share (\%) } & \multirow[b]{2}{*}{ New provider } \\
\hline & T-Mobile & Vodafone & E-Plus & 02 & \\
\hline $\begin{array}{l}\text { Scenario without entry } \\
\text { of a new provider: }\end{array}$ & 19.1 & 21.5 & 11.1 & 48.3 & \\
\hline $\begin{array}{l}\text { Entry of a new provider with } \\
\text { contract specified in Tab. 3: }\end{array}$ & 19.1 & 21.5 & 11.1 & 48.3 & 0 \\
\hline \multicolumn{6}{|l|}{ Off-net $(€):$} \\
\hline 0.2 & 19.1 & 21.5 & 11.1 & 48.3 & 0 \\
\hline 0.15 & 19.0 & 21.4 & 11.0 & 47.3 & 1.3 \\
\hline 0.125 & 15.7 & 17.3 & 9.6 & 34.3 & 23.1 \\
\hline 0.1 & 12.2 & 13.7 & 7.8 & 25.7 & 40.6 \\
\hline \multicolumn{6}{|l|}{ Landline $(€):$} \\
\hline 0.2 & 19.1 & 21.5 & 11.1 & 48.3 & 0 \\
\hline 0.1 & 19.0 & 21.4 & 11.0 & 48.0 & 0.6 \\
\hline 0.05 & 18.7 & 21.2 & 10.9 & 47.8 & 1.4 \\
\hline 0.0 & 10.7 & 8.3 & 7.7 & 40.7 & 32.6 \\
\hline \multicolumn{6}{|l|}{ Free minutes: } \\
\hline $10 \mathrm{~min}$. & 19.0 & 21.5 & 11.0 & 48.0 & 0.5 \\
\hline $15 \mathrm{~min}$. & 18.3 & 20.9 & 10.8 & 47.1 & 2.9 \\
\hline $20 \mathrm{~min}$. & 15.6 & 17.4 & 10.0 & 43.5 & 13.5 \\
\hline $30 \mathrm{~min}$. & 7.7 & 5.2 & 6.6 & 39.1 & 41.4 \\
\hline
\end{tabular}

also be achieved by granting free minutes. However, free minutes are problematical in case of prepaid contracts, because aside from termination rates for incoming calls, only call minutes exceeding the amount of free minutes can create revenues for the provider.

Network effects have a significant influence on the development of the market shares on the cell phone market. However, this influence is not strong enough for explaining why small but much cheaper providers do not experience a more significant growth in market shares in reality. Further influencing factors like switching costs are an important barrier of change and can explain why the cheaper contracts of small providers do not have a greater impact.

\subsection{Critique}

Concerning the simulation results presented above we have to note critically that the parameters used for the cell phone customers are not completely based on empirical data, but partly on our own estimations. Hence the cell phone market modeled above deviates from the actual cell phone market. In order to bridge this gap it will be an important step in future to incorporate anonymous usage data.
Furthermore, although the model is dynamic due to the provider selection of the customers, the customers' usage behavior is not dynamical which means that they do not adapt their behavior to a change in prices or to the network choice of their conversational partners. Likewise, the providers do not adapt their contracts during the simulation and cannot react to a new competitor. However, incorporating these dynamic aspects into the model would make it much more difficult to relate the market results to a concrete influencing factor like pricing.

Additionally, there are some possible extensions to the model itself. For example, we excluded the cost structures of the providers and therefore we could not analyze whether a new provider would be able to finance the contracts examined in this article. In particular, the termination rates for calls to other networks play a crucial role in that context. Thus, extending the simulation environment by adding corresponding cost parameters seems to be a promising approach. In addition to the market share analysis this could help to incorporate a profit and loss calculation for the considered providers. Unfortunately, the calculation of an optimal tariff structure by means of a profit calculation is not possible at the moment, because there is no adequate information about the cost structure of the providers.

Finally, it is increasingly difficult to separate the cell phone market from other sectors like the market of landline telephony. In particular the bundling of cell phone, landline and internet access can only be partially considered in our current model. Furthermore, data services like SMS and MMS are not considered in this context although they are relevant for the selection of contracts in reality. However, this article mainly focuses on voice communication, because in our opinion it is a prerequisite for the market entry of a new provider to offer voice communication. Data services could be added to the model if adequate data was available. In our model we decided not to include data services, because this would have prevented us from relating the effect of different contract designs on the market shares to a certain parameter (price per minute). By focusing on voice communication we can distinguish the customers by means of a single parameter (the monthly minutes) which helps to keep the customer profiles simple.

We intentionally excluded some aspects in our modeling of contracts and customer behavior which are difficult to represent in a simulation model. In particular, hardly quantifiable parameters like brand loyalty, network quality or affinity for certain tariffs (Lambrecht and Skiera 2006a; Lambrecht and Skiera 2006b; Schulze and Gedenk 2005) were not considered in order to prevent the simulation results from being distorted by too many random parameter values. Hence this simulation model is no exact reproduction of reality.

Particularly, it is assumed that in our model the decision behavior of the customers has a stronger focus on prices than in reality. Furthermore, our model presumes that customers are rather well informed about their own usage behavior. Moreover, the model does not incorporate customer expectations about future provider choices of their conversational partners. Therefore, our simulation model neglects group decisions to change to a common provider. Expectations could be added to the model if all customers calculate the cheapest contract at every point of time even if they cannot change their provider at that point of time. Then they could signal their future provider selection to other customers. However, it remains 
an open question how group decisions are actually made in reality on basis of this information.

Another point of criticism is that aspects like provider loyalty and quality are only indirectly addressed by the model. Quality aspects are only modeled implicitly by the inclusion of switching costs. In the future it will be desirable to split the parameter switching costs into several explaining factors. This is facilitated in particular by the fact that our model is based on an ACE approach.

\section{Summary}

By employing ACE models like the one described in this article it becomes more and more possible to reproduce real scenarios very exactly and to gain detailed insights into the effects of different strategies. Thus, completely new pricing models can be analyzed. In our study the informative value of the simulation results was still limited due to a lack of information about the decision behavior of cell phone customers. Furthermore, there is also a lack of exact disaggregated data. However, acquiring such data is basically possible. Therefore, the cell phone market seems to be an appropriate research area for simulating a whole market with its essential mechanisms in a computer-based model. Still, the conclusions drawn from such a model will always only apply in tendency because the complexity of human decision behavior cannot be completely modeled with all its facets.

Apart from that, these models offer great possibilities for planning and forecasting prospects of marketing strategies. Thus, further research in that area seems to be promising. The cell phone market is an interesting object for research on network effects because here it is possible to monetarily assess network effects based on telephone costs and to regard network effects individually for each network participant.

In this article we have shown how the variation of different contract aspects influences the market share of a new cell phone provider. Our simulation revealed that a market entry can be successfully achieved by means of a discount price strategy based on a prepaid contract. It turned out that offnet fees and free minutes have the greatest impact on the market share, while lower acquisition fees or on-net fees do not help to increase the market share.
In the context of further simulations it seems to be valuable to also incorporate offers from service providers without an own cell phone network (e. g. Debitel or Mobilcom). Furthermore, it will be necessary to widen the scope of the model to resolve the critical points mentioned above. Since offers on the cell phone market are more and more bundled with data services and other additional services, it is desirable to incorporate these factors into the simulation model. In addition, besides the consideration of market shares, cost analyses shall be incorporated. Especially the effect of termination rates can then be analyzed, which extends the analysis to aspects of regulation. Finally, it will be a major task for the future to include and examine the effect of qualitative aspects like brand loyalty or appreciation for cell phones on customer behavior.

\section{Acknowledgement}

The authors would like to thank the German Federal Network Agency (Bundesnetzagentur). The comprehensive information about the cell phone market was very helpful for writing this article.

\section{References}

Barabási AL, Albert R (1999) Emergence of scaling in random networks. Science (286):509-512

Beck R, Beimborn D, Weitzel T (2003) The German mobile standards battle. In: Proceedings of the $36^{\text {th }}$ Hawaii international conference on system sciences (HICSS-36). Hawaii

Bitkom (2006) Daten zur Informationsgesellschaft. Bitkom, http://www.bitkom.org/files/ documents/Daten_zur_Informationsgesell schaft_2006.pdf. Accessed 2007-12-02

Blonski M (2002) Network externalities and twopart tariffs in telecommunication markets. Information Economics and Policy 14(1):95-109 BMWi (2008) Mobilfunk Informationen. BMWi, http://www.bmwi.de/BMWi/Navigation/ Wirtschaft/Telekommunikation-und-Post/ mobilfunk, did=187948.html. Accessed 200802-13

Bolle F, Heimel J (2005) A fallacy of dominant price vectors in network industries. Review of Industrial Organization 4(3):197-204

Bundesnetzagentur (2007a) Mobilfunkdienste. Bundesnetzagentur, http://www.bundesnetz agentur.de/enid/ 9645eabd4a09715e1db9056ed3d86b00,0/ Marktbeobachtung/Mobilfunkdienste vw.html\#sms-entwicklung. Accessed 2007-0313

\section{Abstract \\ Sven Schade, Thorsten Frey, Nezar Mahmoud}

\section{Simulating Discount-Pricing Strategies for the GSM-Mobile Market}

The article analyzes network effects on the German GSM mobile telephony market. The authors use an ACE-approach to examine how a new competitor can successfully gain ground in the market with a discount-pricing strategy. In particular they study the impact of several elements of a mobile phone contract like on-net-, landline- or off-net-fees on the competitor's market share. It turns out that it is possible to successfully enter the market with a prepaid contract using a discount-pricing strategy where the single fees only marginally exceed the termination rates, which have to be transferred to foreign network operators.

Keywords: Network effects, Mobile telecommunication, Agent-based computational economics, Pricing strategies 
Bundesnetzagentur (2007b) Teilnehmer-Marktanteile der Netzbetreiber. Bundesnetzagentur, http://www.bundesnetzagentur.de/media/ archive/9042.pdf. Accessed 2007-03-13

Bundesnetzagentur (2007c) Teilnehmerentwicklung im Mobilfunk. Bundesnetzagentur, http:// www.bundesnetzagentur.de/media/ archive/9041.pdf. Accessed 2007-03-13

Bundesnetzagentur (2007d) Teilnehmerentwicklung und Penetration im deutschen Mobilfunkmarkt. Bundesnetzagentur, http://www. bundesnetzagentur.de/enid/ 480e5a85cdae33ce7f13f1294419f2f2,0/ Telekommunikation/Marktbeobachtung_249. html. Accessed 2007-03-13

Buxmann P (2002) Strategien von Standardsoftware-Anbietern: eine Analyse auf der Basis von Netzeffekten. Zeitschrift für betriebswirtschaftliche Forschung 54(5):442-457

Carter M, Wright J (1999) Interconnection in network industries. Review of Industrial Organization 14(1):1-25

Church J, Gandal N (2004) Platform competition in telecommunications. Discussion paper series // Centre for Economic Policy Research, 4659: Industrial organization, Centre for Economic Policy Research, London

David PA, Greenstein S (1990) The economics of compatibility standards: an introduction to recent research. Economics of Innovation and New Technology (1):3-41

Destatis (2004) Neuberechnung des Verbraucherpreisindex für Telekommunikationsdienstleistungen auf Basis 2000. Destatis, http://www. destatis.de/jetspeed/portal/cms/Sites/ destatis/Internet/DE/Content/Statistiken/ Preise/Verbraucherpreise/Tabellen/Content75/ Telekommunikation, property=file.pdf. Accessed 2008-03-15

Destatis (2008) Preisindex für Telekommunikationsdienstleistungen. Destatis, http://www. destatis.de/jetspeed/portal/cms/Sites/ destatis/Internet/DE/Grafiken/Preise/ Diagramme/Telekommunikation.psml. Accessed 2008-10-01

Dialog (2006) Achte gemeinsame Marktanalyse zur Telekommunikation. Dialog Consult GmbH, http://www.vatm.de/content/studien/ inhalt/27-09-2006.pdf. Accessed 2007-02-01

Doganoglu T, Grzybowski L (2006) Estimating network effects in mobile telephony in Germany. Mimeo, Ludwig Maximilian Universität München

Ebert G, Baake P, Heitzler S, Wey C (2006) Die Rolle staatlicher Akteure bei der Weiterentwicklung von Technologien in deregulierten TKMärkten. Deutsches Institut für Wirtschaftsforschung, http://www.innovationsanalysen.de/ de/download/endberichtTK-Maerkte.pdf. Accessed 2007-03-13

Grajek MEM (2003) Estimating network effects and compatibility in mobile telecommunications. CIG Working Papers, SP II 2003-26, Wissenschaftszentrum Berlin (WZB), Research Unit: Competition and Innovation (CIG)

Haucap J (2004) Wettbewerb und Regulierung im Mobilfunk aus Sicht der ökonomischen Theorie. In: Kruse J, Haucap J (eds) Mobilfunk zwi- schen Wettbewerb und Regulierung. Fischer, München, S 47-76

Hein O, Schwind M, König W (2006) Scale-free networks: the impact of fat tailed degree distribution on diffusion and communication processes. WIRTSCHAFTSINFORMATIK 48(4):267275

lyengar R (2004) A structural demand analysis for wireless services under nonlinear pricing schemes. Mimeo, University of Pennsylvania

lyengar R, Ansari A, Gupta S (2007) A model of consumer learning for service quality and usage. Journal of Marketing Research 44(1):529544

Katz ML, Shapiro C (1986) Technology adoption in the presence of network externalities. Journal of Political Economy 94(4):822-841

Kim MK, Park MC, Jeong DH (2004) The effects of customer satisfaction and switching barrier on customer loyalty in Korean mobile telecommunication services. Telecommunications Policy 28(2):145-159

Koski H, Kretschmer T (2004) Survey on competing in network industries: firm strategies, market outcomes, and policy implications. Journal of industry, competition and trade 4(1):5-31

Koski H, Kretschmer T (2005) Entry, standards and competition: firm strategies and the diffusion of mobile telephony. Review of Industrial Organization 26(1):89-113

Kruse J (2003) Regulierung der Terminierungsentgelte der deutschen Mobilfunknetze. Wirtschaftsdienst 3:203-209

Lambrecht A, Skiera B (2006a) Paying too much and being happy about it: causes and consequences of tariff choice biases. Journal of Marketing Research 18(2):33

Lambrecht A, Skiera B (2006b) Ursachen eines Flatrate-Bias - Systematisierung und Messung der Einflussfaktoren. Schmalenbachs Zeitschrift für betriebswirtschaftliche Forschung 58(8):588-617

Pepels W (1998) Einführung in das Preismanagement. Oldenbourg, München

Schulze T, Gedenk K (2005) Biases bei der Tarifwahl und ihre Konsequenzen für die Preisgestaltung. Zeitschrift für Betriebswirtschaft 75(2):157-184

Shin DH (2005) A study of mobile number portability effects in the United States. Telematics and Informatics 24(1):1-14

Stiftung Warentest (2006) Die billigsten Handytarife. Stiftung Warentest (9):38-39

Tesfatsion L (2003) Agent-based computational economics. Working paper, http://www.econ. iastate.edu/tesfatsi/acewp1.pdf

Weitzel T, König W (2003) Computational Economics als wirtschaftsinformatischer Beitrag zu einer interdisziplinären Netzwerktheorie. WIRTSCHAFTSINFORMATIK 45(5):497-502

Weitzel T, Wendt O, von Westarp F (2000) Reconsidering network effect theory. In: Proceedings of the $8^{\text {th }}$ European conference of information systems (ECIS 2000) Wien

\section{Markenorientierte}

Mitarbeiter-

Kunden-Interaktion

オ

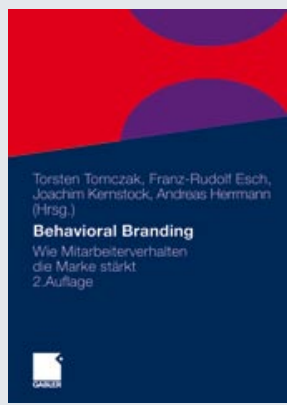

Tomczak, Torsten / Esch, Franz-Rudolf / Kernstock, Joachim / Herrmann, Andreas (Hrsg.)

Behavioral Branding

Wie Mitarbeiterverhalten die Marke stärkt

2., akt. u. erw. Aufl. 2009.

XIV, 486 S. Geb.

EUR 72,00

ISBN 978-3-8349-1745-4

Die Autoren zeigen Methoden zur Analyse der Schwachstellen im Brand Behavior des Mitarbeiters auf. Sie entwickeln ein strategisches Konzept, um die Marke durch Mitarbeiter-Kunden-Interaktion zu stärken und stellen zahlreiche Instrumente vor, aus denen der richtige Mix für das Brand Behavior im Unternehmen abgeleitet werden kann.

Einfach bestellen: kerstin.kuchta@ gwv-fachverlage.de Telefon +49(0)611. 7878-626

KOMPETENZ IN SACHEN WIRTSCHAFT

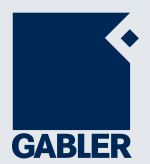

